enormous animal, of great strength, but clumsy, awkward, and slow in its movements. It wallowed in the mud, lazily chewed its food of grass and tender twigs, and stretched itself to rest among the reeds or grass on the river's edge. From this apathetic conclition it would be roused only by the attack of a rival, of a mammotb, of a rbinoceros, or of some one of the great carnivorous animals of that distant epoch. It would then rush enraged on its adversary, and endeavour to lay it low with its formidable horn.

The discoveries of remains of the elasmotherium show that it once wandered over the greater portion of Europe, from the Ural to the Rhine, and as far south as Sicily. It is also highly probable that later palæontological discoveries will show its existence in Asia, in company with the other large mammals, whose remains have been so well preserved in Siberia.

It was also in all probability contemporary with the men of the stone age, its remains occurring in the same deposits, in which the anthropologist finds the flints, collections of bones, and other evidences of prehistoric man. From their weapons the elasmotherium had probably little to fear.

In connection with this interesting discovery $\mathrm{Dr}$. Brandt recounts a tradition of a tribe of Tartars in South Siberia, which describes the death of an enormous black ox. It possessed, however, but a single horn, and that of such size that it could be transported on sledges only. Possibly a reference to the elasmotherium.

\section{UNDERGROUND MONSTERS}

$I^{\mathrm{N}}$ a former number (vol. xvii. p. 325) we gave some account of a curious underground monster, the Minhocao, supposed to exist in Brazil. Dr. Spencer Baird, of the Smithsonian Institution, sends us an interesting document, which shows that the belief in such a monster is not confined to Brazil, but is shared in by the people of Nicaragua. In the Gaceta de Nicaragua for March Io, 1866 , is a long letter signed "Paulino Montenegro," containing a circumstantial account of an object possessing very much the same attributes as the Minhocao. The letter is dated Jinotega, Nicaragua, February 21, 1866. The writer states that he went to Concordia on private business, when he heard on the I7th of a serpent having taken up its abode at a place called La Cuchilla, within the jurisdiction of the village. Along with some friends, M. Montenegro set out on the 18 th to examine in to the foundation of the report. A tradition concerning such a monster has existed from "time immemorial." After having travelled on that day about two leagues (I league $=2.6$ English miles) north-east from the village, they reached the spot where the inhabitants of the neighbourhood had traced signs and tracks, which, M. Montenegro states, positively prove the existence of such an animal.

The most detailed accounts stated that here, some five years before, a sort of platform of about fifty varas diameter had been formed at the foot of a large rock cropping out from a hillside. One of the neighbours had established there an orchard, though no one had been able to account for this new formation. Three years before, however, people began to observe that this little piece of level ground was gradually deepening, and that in the month of November the base of the rock adjoining it became exposed and worn from some agency, notwithstanding that there was not sufficient water to cause the phenomenon. At the same time mighty trees (robles ${ }^{1}$ ) were observed to become uprooted and to fall

x "Roble," in Spanish, means an oak. The same name is found through various parts of Spanish America, applied to trees belonging to very different botanical families, having no natural affinities among each other, and also none to the "Cupuliferæ." On the River Atralo, in New Granada, South America, a huge tree, a species of Tecoma, is called "roble." The name "roble," no doubt, is given to these different forms merely on account of some external resemblance $\mathrm{t}$ ) an or giral Spanish species of cak. in great disorder, while immense rocks were moved and shifted their foundations so much, that in the following month of December, during one night, the road from Chichiguas and Cuchilla to San Rafael del Norte was destroyed by a multitude of cracks and clefts, which had suddenly opened. At that time the ground was observed to be undermined, falling in at intervals. These occurrences were observed some three days before $M$. Montenegro and his friends visited the place, which they saw all to be in accordance with the statements. Immediately on examining the locality for themselves they came to the conclusion that there were signs not of one but of two animals, probably of the shape of huge fishes.

In commencing their work these animals seemed to pursue a kind of an upheaving movement. As the bottom of their hiding-place was loose, shifting ground, the surface of this was seen to give way, while trees were shaken out and came down crashing. The noise of this seemed to scare the animals away. One of them--believed to have been the male on account of its larger size and greater strength-took to the left in descending, but always in a parallel direction with and along the slope of another hill, which here terminated. As it broke through the banks of a ravine, which measured about twenty varas in width and nine feet in depth at its greatest opening, he passed with his head underground. The thrown-up soil showed the tracks of the bead, which left its marks both in the soil and on the roots of the trees, which were broken; the broken pieces being four inches thick. The main part of the body, which certainly must have passed here uncovered, left its traces at the bottom of the ravine. Passing out from this the animal entered upon ground more level and friable, which it went through at a depth of five quarters ( $\mathrm{I}^{*} 25$ varas), forming a furrow and leaving behind a ridge more than one vara high. Following the ravine for a distance of about sixty varas it encountered two deep ditches, when it turned and traced its way back, and, approaching the aforesaid ravine, took to the bed of a pond and disappeared perpendicularly.

The other animal, which left behind a smaller track, and therefore was believed to have been the female, went at once to the right, to the outlet of the pond of water before referred to, leaving behind it everywhere the same marks as the other. When it reached the two deep ditches it turned back also, and undoubtedly encountered its companion afterwards.

The whole ground had become irregularly disturbed and broken up, and the power of these animáls is shown by their being able not only to throw up huge masses of soil but even to move rocks weighing more than thirty quintals.

The animals seem to be covered with a skin clad with scales or plates, the markings of which, imprinted on the soft clay or loam, bear much resemblance to those of the garrobo ${ }^{1}$ in the mud. It appears that the shape of these animals must be like that of the guapote. ${ }^{2}$ The length of the body is at least twelve varas, the height three, and its thickness $\mathrm{x} \cdot 5$ varas.

A tradition about such an animal as this has been kept up unaltered, without contradiction, for more than a hundred years. It is described in general as a large snake, and called "sierpe," on account of its extraordinary size, and living in chaquites. ${ }^{3}$ One is said to have been once killed by lightning the moment it had left its hiding-place in the river "Sebaco viejo."

\section{TWO AUSTRALIAN GEOLOGISTS}

$A$ USTRALIA has recently lost two of its most eminent geologists, the Rev. W. B. Clarke and Mr. Richard Daintree. The death of Mr. Clarke we noted some weeks

I 2 "Garrobo" and "guapote" are names of which the exact application

cannot be ascertained. ciailsm; probably pools or ponds is meant in the present case. 
ago, and now by the kindness of a correspondent we are able to give a few details as to his career.

The Rev. W. B. Clarke was born on June 2, 1798, at East Bergholt, in Suffolk. In October, 1817 , he went to Cambridge and entered into residence at Jesus College. In January, I821, he took his B.A. degree, and in July, 1824, he was made M.A. and a member of the Senate. From May, 1821, until November, 1824, he officiated as curate of Ramsholt, Nedging, Whatfield, Chellesworth, and Brantham; after this he became curate for a time in his native parish. The rector seems to have had a proper appreciation of his talents, for he not only allowed but enjoined him to travel during a portion of each year, a privilege of which Mr. Clarke availed himself in order to pursue and complete the geological and mineralogical studies that he had commenced at the University under the teaching of Prof. Sedgwick and Dr. Clarke, the celebrated traveller in the Holy Land. During this period he made some fifteen distinct journeys of exploration either on the Continent or in different parts of his native land, enlarging his experience and acquiring fresh stores of information. In 1823 he was presented by Lord de Manley to a small vicarage in the county of Dorset, with a written promise of the succession to a desirable rectory in Gloucestershire. Having, however, rheumatic affection, and seeing no immediate prospect of succeeding to the Gloucestershire living, he determined to take a voyage to Australia, and arrived in Sydney in the year 1839. He appears to have found in Australia a fitting field, both for his labours as a clergyman and for the prosecution of his favourite studies in geology and mineralogy, and he at once applied himself to both. He had been considerably influenced in deciding to make Australia his home by correspondence he had had with the late Sir Thomas Mitchell, formerly Surveyor-General of the colony, and with the late Bishop Broughton, who had been his fellow-undergraduate at Cambridge. The first charge to which he was appointed was that of King's School, Parramatta, a position which he continued to fill until the beginning of the year $184 \mathrm{I}$, after which he retired from the school, and attended only to his clerical duties. In 1844 he took charge of the parish of Willoughby, North Shore, with which he remained connected till 1870 .

Mr. Clarke filled many positions of honour and distinction in connection with his own communion, and with learned and scientific bodies in various parts of the world. He was Fellow of St. Paul's College, vicepresident of the Royal Society of New South Wales, trustee of the Australian Museum, trustee of the Public Free Library, Fellow of the Geological Society of England since the year 1826, member of the Geological Society of France, member of the Royal Geological Institute of Austria, member of the Royal Geological Society of London, \&c., \&c. In the department of science to which he had more particularly devoted his attention, he was regarded as an authority by all geologists. Perhaps his largest and best-known work is that entitled "The Southern Gold-fields," which contains an exhaustive description of the auriferous deposits throughout Australia. This work was written in consequence of Mr. Clarke having been commissioned by the Government to visit and report upon the principal goldproducing localities in the colony. A number of his papers were at different times read before the Royal Society of New South Wales, and are preserved among its records. They are almost entirely confined to subjects relating to geology, mineralogy, and meteorology.

Some two or three years ago Mr. Clarke was elected a member of the Royal Society of England--an honour which has been so rarely conferred upon colonial savans that $\mathrm{Mr}$. Clarke valued it perhaps more than all the other distinctions he had won, especially as the honour was conferred upon him by the unanimous and spontaneous action of the Society. Mr. Clarke died on June I6.

The announcement of the death of Mr. R. Daintree, C.M.G., F.G.S., will be read with deep regret alike in this country and the Australian Colonies, more especially Victoria and Queensland. Next perhaps to that of Mr. Clarke, his name has been more intimately associated with geological science at the Antipodes than that of any other observer, more particularly in connection with the former province.

On his first arrival in Victoria Mr. Daintree became connected with Mr. A. R. C. Selwyn, F.R.S. (now Director of the Geological Survey of Canada), in the geological survey of that colony, and did good work in the exploration of the Bass River, the survey of the Cape Patterson Coal-field, and other difficult explorations. He was also engaged in the survey of a large tract of country to the south-west of Melbourne, around the now flourishing town of Geelong, comprising the Barrabool Hills, the Anakil, and other minor ranges, and to the north the districts of Ballan and Bacchus Marsh. An accomplished photographer, his knowledge of this science was turned to good account in the preparation of a large number of photographs illustrative of the general geology of Victoria and Queensland, and more especially of the physical structure of the gold fields, and the methods in operation for the mining and extraction of gold. The formation and mode of occurrence of the precious metal attracted a good deal of his attention, more especially with regard to its presence in rocks associated with dioritic dykes in Queensland.

Mr. Daintree's connection with the Geological Survey of Victoria commenced in 1854 , and, with the exception of a short interruption in $1857-8$, continued down to 1864. In that year he left Victoria for North Queensland, and settled there as a "squatter," continuing at the same time to interest himself in matters geological. In 1869 the Queensland government appointed him government geologist for the northern half of the colony - a choice amply justified by the remarkably good work he performed whilst acting in that capacity. Queensland owes to Richard Daintree no ordinary debt of gratitude for the important part he took in the development of her mineral resources, the discovery of several important gold fields having followed quickly upon his prognostications.

Daintree's geological map of Queensland will give some idea of the vast tracts of country traversed and reported on during the course of his residence in that province, and on which the geological boundaries of the various formations were laid down with great care and precision. Whilst on this subject we would call attention more particularly to the definite delineation of the boundaries of the great secondary formation of north-eastern Australia about which little, comparatively speaking, was known up to that time, except the occurrence of typical fossils at a few isolated localities. The great tertiary series, aptly designated by Daintree the "Desert Sandstone," was shown to have extended over the greater part of Australia at one time.

In 1871 Mr. Daintree was appointed Special Commissioner for Queensland to the International Exhibition of I 872 , and organised the admirably-arranged Queensland annexe, which was, in that and succeeding exhibitions, so universally admired. An experienced and determined bushman, he had, during his Australian career, paid too little attention to the preservation of his health, and in all probability laid the seeds of the complaint which afterwards terminated fatally. Soon after his appointment in March, 1872, as Agent-General for the Queensland Colony in London, his health began to give way, and his condition caused much anxiety to his numerous friends. Notwithstanding his removal to a warmer climate during our winters, signs of pulmonary disease 
rapidly manifested themselves. He died last month, at the early age of forty-seven years. By his death there has passed from amongst us a true, most unselfish, and large-hearted man, a true friend, and a most agreeable companion. He was an accomplished geologist, a close and accurate zoological observer, a thoroughly practical chemist, and a photographer of no mean order. It will be long ere the vacancy in Australian science will be filled.

\section{THE BRITISH ASSOCIATION}

TWENTY-ONE years have passed since the British Association met in Dublin. It was then under the presidency of Dr. Lloyd, the venerable, but still hale, Provost of Trinity College. On Wednesday next, as our readers are aware, the forty-eighth annual gathering of this congress of science once more meets in the metropolis of Ireland, the President-Elect again being an eminent mathematical physicist, Dr. Spottiswoode.

Notwithstanding the fact that Dublin is now as easy of access from London as Edinburgh, and as near in point of time, yet the average Englishman knows far more of Paris or Switzerland than he does of the sister-isle. We trust the forthcoming meeting in Dublin will help to remove much of the prejudice with which Ireland is regarded, prejudice which proceeds from ignorance. For instance, not long ago an eminent scientific Englishman having been asked to lecture in Dublin, seriously inquired whether it would be advisable to be armed with a revolver, exhibiting a fear less reasonable than that of the man who, on a visit to Christiania, took precautions against being attacked by bears. Dublin no longer deserves the second adjective in the epithet of "dear dirty Dublin," in fact, its well kept streets, its splendid buildings and squares, the activity of its commercial and intellectual life, delight and surprise the stranger. In point of situation it is, perhaps (at least next to Edinburgh, our Scotch friends will think), the most beautiful capital in the world, backed by the Dublin and Wicklow Mountains, flanked on one side by the Hill of Howth, and on the other by Bray Head, the Bay of Dublin, with its clear blue water, is even comparable in beauty to that of Naples, if corresponding atmospheric conditions be granted.

Unusual facilities have been offered by the railway and steam-boat companies for the conveyance of visitors to Dublin. To some of our readers it may be convenient if we summarise the ways of reaching Dublin from London. The quickest route is of course by the Irish day or night mail from Euston Square : for example, leaving London at 8.25 P.M., one is landed in Dublin before seven the next morning. The splendid and perfect arrangements of the mail steamers from Holyhead to Kingstown are too well known for us to describe them. Recently the London and North Western Company have built two magnificent steamers, which run during the day from Holyhead to Dublin, and vice versâ. The fare is less than by the mail, and the boats are quite as large and sumptuous as the mail-boats, though not quite so fast. To those who intend travelling second class (there is no third by the mail) we should recommend their selecting the North Western boats from Holyhead to North Wall, Dublin; second class passengers being allowed to use the first class saloon without extra charge. The night boat, which meets the 5 P.M. train from Euston, is not quite so fine as the day boat, but the visitor has the advantage of entering the Bay of Dublin by daylight, reaching North Wall about 7 A.M. At the present season of the year no alarm need be felt on the score of sea-sickness by those who travel in the mail-boats from Holyhead to Kingstown. The boats are so large and steady that even with a considerable wind little motion is felt; and the passage is very short, about four and a half hours being the average.
Anotber route is via Liverpool to Dublin, these are good? boats. Lastly, to those who prefer a long sea-trip and can spare the time, nothing is more pleasant than going from London to Dublin direct by steamer. So much for transit. As regards accommodation in Dublin, the Executive Committee have provided a very complete list of lodgings; and the hotels, we understand, have not raiser their usual tariffs.

The arrangements of the meeting we have already announced. The sections will meet in Trinity College, the addresses will be delivered in the Exhibition Palace, and lectures will be given by $\mathrm{Mr}$. Romanes and Prof: Dewar an August 16 and I9. On August 15 a soirée will be given by the Royal Dublin Society to the Association. This promises to be a very brilliant affair. The Department of Science and Art has allowed a liberal selection of objects from the South Kensington Museum and the Science Collection to be lent for the occasion. Electrotype reproductions of many of the most interesting relics exhibited in the Loan Collection of Scientific Apparatus will be shown at this soirée, together with other curiosities from South Kensington. Dr. Spottiswoode has also kindly lent one of his new leviathan condensers which, used in conjunction with an enormous induction coil lent by $\mathrm{Mr}$. Horatio Yeates, will be sure to attract much attention during the evening, and further, the Stereoscopic Company have promised to exhibit the phonor graph at this soirée. A conversazione will also be given by the Royal Irish Academy, when its unrivalled museum of Irish archæology and antiquities will be seen to advantage and with interest by the members of the Association.

No neighbourhood lends itself so easily to beautiful excursions as that around Dublin, and the excursion programme this year is most varied and complete. Here is the list for Saturday, August 17 :-

High Park and Artane Reformatories, to be entertained at the Artane Reformatory; St. Doulough's Church, Malahide Castle, and antiquities of Swords, to be entertained by the Right Hon. Lord Talbot de Malahide; Bray Head, Kilruddery Demesne, Hollybrook, Charleville, the Dargle and the Scalp, to be entertained by the Right Hon the Earl of Meath; Maynooth R. C. College, Carton, Lord Annaly's and Phœnix Park, to be entertained by his Grace the Duke of Leinster; Howth and Ireland's Eye (walking excursion), to be entertained to afternoon tea by residents of Howth ; Lucan and Leixlip, Valley of the Liffey, Woodlands and Phœnix Park, déjeuner will be provided by committee at Lucan; Irish Lights Board, Dublin Bay--steamer Alexandra, to be entertained on board the steamer by Irish Lights Board; London and North Western Railway-steamer Rose, to be entertained on board the steamer by Committee; Glencree. Reformatory, Killakee Demesne, Waterfall, Dargle and Enniskerry, to be entertained at Glencree Reformatory by the Managers.

For Thursday, August 22 this is the list :-

Glendalough and Seven Churches, to be entertained at Newrath Bridge; Vartry Waterworks, déjeuner at Vartry Lodge; Vale of Avoca, déjeuner at Glenart Castle, given by the Earl of Carysfort, and at Skelton Abbey, by the Earl of Wicklow; Boyne, déjeuner at Drogheda ; Cashel, déieuner at Limerick Junction ; Parsonstown, déjeuner at Birr Castle, given by the Right Hon. the Earl of Rosse Powerscourt, déjeuner at Powerscourt Castle given by Viscount Powerscourt; Curragh Camp, déjeuner at Stand House, Curragh ; Kilkenny, déjeuner at Kilkenny Castle, by the Most Noble the Marquis of Ormonde; and on Friday, August 23, an excursion is arranged to Belfast, luncheon being provided at Glanmore, Lisburne, by Messrs. Richardson and Sons, with dinner at Belfast.

Dublin is famous for its hospitalities, and, amid other festivities, the following have been arranged:- On the morning of Monday, the Igth, members will be enter- 